\title{
Mutation detection in the promoter region of survivin gene on N-methyl-N-nitrosourea induced colon tumor model in experiment
}

\author{
Budak $\mathrm{M}^{1}$, Korpinar $\mathrm{MA}^{2}$, Kalkan $\mathrm{T}^{2}$, Tuncel $\mathrm{H}^{2}$
}

Trakya University, Medical Faculty, Department of Biophysics, Edirne, Turkey. genomicdna2@yahoo.com

\begin{abstract}
Survivin (also known as BIRC5) is one of the first reported inhibitors of apoptosis proteins (IAPs), which is an important family of proteins that regulate apoptosis. It is developmentally regulated and expressed during cell differentiation in humans, mice and rat. Survivin is expressed in a series of human cancers and it has been widely accepted that survivin is strongly related to the onset and development of cancer. In the present study, we tried to determine differences in the promoter region of survivin gene in colon tissue samples from $\mathrm{N}$-methyl-N-nitrosourea (MNU) induced rat colon tumor model and control group. Polymerase chain reaction (PCR) - single strand conformation polymorphism (SSCP) analysis was used for this aim. No significant differences were found in the promoter region of survivin gene between the normal and tumor tissues (Tab. 2, Fig. 1, Ref. 16). Text in PDF www.elis.sk.

Key words: survivin, promoter, single strand conformational polymorphism (SSCP), rat.
\end{abstract}

Programmed cell death is also called apoptosis or physiological cell death, plays diverse roles in embryogenesis and normal homeostasis, as well as in tumorigenesis $(1,2)$. Apoptotic processes are regulated by a few factors, which have inhibitory or stimulatory effects. Survivin is one of these factors. It is a member of the IAP family, which is situated on chromosome $17 \mathrm{q} 25$, is a unique bifunctional protein that inhibits apoptosis by suppressing caspase- 3 and caspase-7, and modulating the G2/M phase of the cell cycle by associating with the mitotic spindle microtubules. Inhibitors of apoptosis proteins are a family of negative regulators of apoptosis. Survivin plays a key role in the regulation of apoptosis and cell division $(3,4)$. Survivin is expressed in a cell cycle-regulated manner with a peak in the G2/M phase of the cell cycle, and a rapid down regulation level, and mediated by cell cycle-dependent elements (CDEs) and cell cycle homology regions (CHRs) located in the proximal region of the survivin promoter (5-6).

It is developmentally regulated and expressed during cell differentiation in humans, mice and rats. Survivin has been reported to be expressed in most human malignant tumors but not in normal differentiated tissues of adult human, with the exception of thymus, basal colonic epithelium, endothelial cells, and neural stem cells

${ }^{1}$ Trakya University, Medical Faculty, Department of Biophysics, Edirne, Turkey, and ${ }^{2}$ Istanbul University, Cerrahpasa Medical Faculty, Department of Biophysics, Istanbul, Turkey

Address for correspondence: M. Budak, Trakya Universitesi, Tip Fakultesi, Biyofizik A.D., Edirne, Turkey.

Phone: +90. 284.2357641

Acknowledgement: This study was funded by Istanbul University Research Fund (Project No: BYP-415/060504). during angiogenesis. High survivin expression has been found in the majority of human cancers (7-10).

Survivin may act both as a mitotic regulator and a cytoprotective factor at cell division, a pathway potentially exploited in cancer where the survivin gene is broadly up-regulated (11-13). Our aim in this study was to observe any difference in promoter region of survivin gene in N-methyl-N-nitrosourea (MNU) induced rat colon tumor model using polymerase chain reaction (PCR)- single strand conformation polymorphism (SSCP) analysis.

\section{Materials and methods}

Samples

We used 28 formalin fixed paraffin embedded Wistar albino rat colon tissues that were obtained from a previous research. Briefly, animals were divided in 2 groups (Tab. 1), MNU and control group. Preparation of the rat colon tumor model, the paraffin embedding procedure is described in a previous research (14).

\section{DNA Extraction}

Paraffin embedded colon tissues were cut in to $4 \mu \mathrm{m}$ thick slices and placed on microscope slides. Then microscope slides were kept in the clean xylene for 10 minutes twice. To remove the residual xylene, the samples were washed twice with absolute ethanol for ten minutes. After the deparaffinization step slides

Tab. 1. Experimental groups.

\begin{tabular}{lcc}
\hline Groups & Sample Codes & Sample (n) \\
\hline Control Group & M1-M10 & 10 \\
MNU Group & M41-M58 & 18 \\
\hline
\end{tabular}


were kept in the room temperature for drying. Qiagen Qiamp DNA FFPE Tissue Kit (Venlo, Netherlands) was used according to the manufacturer's protocol for the extraction of DNA.

\section{PCR amplification}

DNA was amplified with primers designed using the web site http://frodo.wi.mit.edu/

to produce a 280 bp product of proximal region of the survivin promoter. The primers forward; 5' - AAGGCGACTTTTTCCAGAGG- 3' and reverse; 5'-TTAAGGTACAGCTGCCAGGTC-3' were included. Each $50 \mu$ reaction mixture contained 10X DreamTaq ${ }^{\mathrm{TM}}$ Green Buffer $5 \mu$, dNTP Mix $2 \mathrm{mM}$ each 5 $\mu \mathrm{l}$ and primers $0.5 \mu \mathrm{M}$, Template DNA $1 \mu \mathrm{g}$, DreamTaq ${ }^{\mathrm{TM}}$ DNA Polymerase $1.25 \mathrm{U}$ (Fermentase - Lithuania) with nuclease-free water to $50 \mu \mathrm{l}$. PCR was conducted as follows: $95{ }^{\circ} \mathrm{C}$ for $5 \mathrm{~min}$, followed by 30 cycles of denaturation at $95{ }^{\circ} \mathrm{C}$ for 30 second, $57^{\circ}$ for 90 second, $72{ }^{\circ} \mathrm{C}$ for 90 second, completed with a final elongation step at $72{ }^{\circ} \mathrm{C}$ for 5 minute. PCR products were subjected to electrophoresis on a $2 \%$ agarose gel and stained with ethidium bromide.

\section{Single-strand conformation polymorphism (SSCP)}

SSCP was used to observe any difference inthe promoter region of survivin between MNU and control groups. Genomic DNA was isolated as described above. A volume of $8-10 \mu 1$ of PCR product diluted with $10 \mu \mathrm{l}$ denaturating buffer (95\% formamide, 10 $\mathrm{mM} \mathrm{NaOH}, 0.25 \%$ bromphenol blue, and $0.25 \%$ xylene cyanol) was denatured by heating at $95{ }^{\circ} \mathrm{C}$ for 10 minutes and immediately placed in ice. The denatured PCR samples were run on 12 $\%$ acrylamide/bis gel in $0.5 \mathrm{X}$ TBE buffer for 3.5 hours at $200 \mathrm{~V}$. Ice cooled water circulation with electric pump was applied to buffer cooling of the SSCP system. Gels were silver stained to visualize DNA bands (5).

\section{Results}

PCR amplifications of the total of six samples from all groups failed so we discarded them from consideration. Final distribution of sample count in the groups is shown in Table 2. SSCP results can be seen in the Figure1.

\section{Discussion}

Previous studies showed the importance of survivin overexpression in animal tumor models. Xiao-Dong Zhu and et al used $\mathrm{N}$-methyl-N'-nitro-N-nitrosoguanidine (MNNG) and high dose sodium-chloride diet to induce rat gastric tumor model. In this model they tried to show survivin expression in gastric carcinoma model of rats like in human gastric carcinoma. According to their results, survivin expression in glandular stomachs of nor-

Tab. 2. PCR amplified samples.

\begin{tabular}{lc}
\hline Groups & Sample (n) \\
\hline Control Group & 7 \\
MNU Group & 14 \\
\hline
\end{tabular}

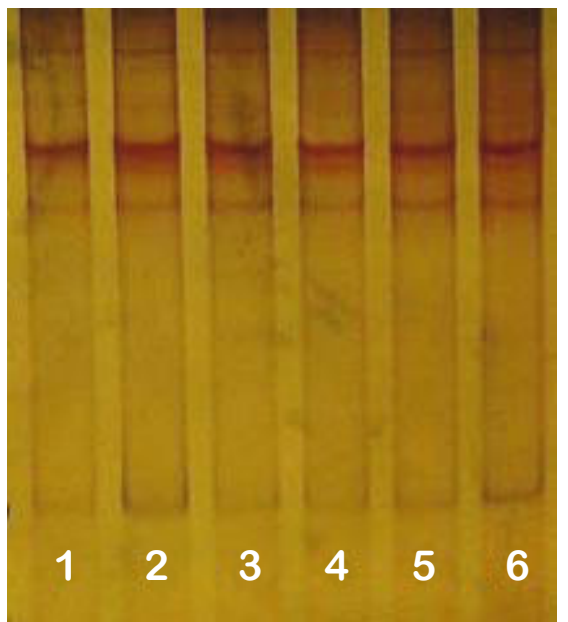

Fig. 1. Analysis of survivin promoter genotypes by single - strand conformation polymorphism. Line 1, 2 are control groups, Line 3 - 6 are $\mathrm{MNU}$ induced rat colon tumors.

mal rats, of rats in middle induction period, in adenocarsinomas and tissues adjacent to tumor were $0 \%, 40.0 \%, 78.3 \%$ and 38.9 $\%$, respectively (15). Iskandar and Al-Joudi detected the expression of the survivin homogues and their subcellular distribution in formalin-fixed paraffin-embedded tissue sections of fetal and normal adult tissues of rat in their studies by using immunohistochemistry. Their results showed that was survivin abundantly and prominently expressed during fetal development in rats (12). In a similar study Lin Fan et al. showed that overexpression of survivin promoted mesenchymal stem cell (MSCs) survival in the infarcted myocardium and also enhanced the secretion effect of MSCs for vascular endothelium growth factor in vitro and in vivo in a rat model. This led to angiogenesis in the infarcted myocardium and ultimately reduced the infarct size, inhibited myocardial remodeling, and resulted in substantial recovery of cardiac function after myocardial infarction (16). In another study, Chen et al investigated the protein and mRNA expression of survivin, as well as the methylation status of the $\mathrm{CpG}$ sites in exon 1 of the survivin gene for 7,12 dimethylbenz[a]anthracene (DMBA)induced hamster buccal- pouch squamous-cell carcinomas. Cytoplasmic stainings of survivin protein and mRNA were detected in all of the hamster buccal-pouch tissue specimens treated with DMBA, whereas neither survivin protein nor survivin mRNA were noted for all of the untreated and mineral oil-treated hamster buccal-pouch tissue specimens. Furthermore, all the untreated and mineral-oil treated samples had a survivin-methylated allele, whereas the DMBA-treated cancerous tissues showed no evidence of survivin methylation. Their results suggest that survivin may play an important role in DMBA-induced hamster buccal-pouch carcinomas, and that the gene expression may be modulated by an epigenetic mechanism (7).

Survivin shows differential expression in cancer and interconnects multiple pathways required for tumor maintenance, which makes it a valuable marker in cancer genetics. The goal of our study was to determine the status of promoter region of survivin 


\section{$554-556$}

gene in MNU induced colon tumor model in rat. We did not see any difference in the proximal region of the survivin promoter between the control group and MNU group. We are planning to further investigate other sections of survivin gene in this model.

\section{References}

1. Kerr JF, Wyllie AH, Currie AR. Apoptosis: A Basic Biological Phenomenon with Wideranging Implications in Tissue Kinetics. Br J Cancer 1972; 26: 239-257.

2. Soini Y, Paakko P, Lehto VP. Histopathological Evaluation of Apoptosis in Cancer. Am J Pathol 1998; 153: 1041-1053.

3. Sasaki T, Beatriz SM, Gerald RH, Gregory AH. Expression of survivin, an inhibitor of apoptosis protein, in tumors of the nervous system. Acta Neuropathol 2002; 104: 105-109.

4. John CR. Mechanisms of Apoptosis. Am J Pathol 2000: 157; 14151430 .

5. Boberly AA, Murvai M, Szarka K et al. Survivin promoter polymorphism and cervical carcinogenesis. J Clin Pathol 2007; 60: 303-306.

6. Gazouli M, Tzanakis N, Rallis G. Theodoropoulos G et al. Survivin $-31 \mathrm{G} / \mathrm{C}$ promoter polymorphism and sporadiccolorectal cancer. Int $\mathrm{J}$ Colorectal Dis 2009; 24: 145-150.

7. Chen YK, Hsue S, Lin LM. Archives of Oral Biology 2005; 50: 593-598.

8. Chiou SK, Moon WS, Jones MK, Tarnawski AS. Survivin expression in the stomach: implications for mucosal integrity and protection. Biochem Biophys Res Commun 2003; 305: 374-379.
9. Upadhyay R, Khurana R, Kumar S, Ghoshal UC, Mitta B. Role of Survivin Gene Promoter Polymorphism $(-31 \mathrm{G} / \mathrm{C})$ in Susceptibility and Survival of Esophageal Cancer in Northern India. Ann Surg Oncol 2011; $18 ; 880-887$.

10. Deveraux QL, Reed JC. IAP family proteins-suppressors of apoptosis. Genes Dev 1999; 13: 239-252.

11. Han CH, Wei Q, Lu KK, Liu Z, Mills GB, Wang LE. Polymorphisms in the survivin promoter are associated with age of onset of ovarian cancer. Int J Clin Exp Med 2009; 2: 289-299.

12. Iskandar ZA, Al-Joudi FS. Expression of survivin in fetal and adult normal tissues of rat. Malays J Pathol. 2006; 28(2):101-105.

13. Paola F, Nathan RW, Giodini A, Survivin exists in immunochemically distinct subcellular pools and is involved in spindle microtubule function. J Cell Sci 2002; 115 (Pt 3): 575-585.

14. Tuncel H, Shimamoto F, Cagatay P, Kalkan MT. Variable E-cadherin expression in a MNU-induced colon tumor model in rats which exposed with $50 \mathrm{~Hz}$ frequency sinusoidal magnetic field. Tohoku J Exp Med 2002; 198 (4): 245-249.

15. Zhu XD, Lin GJ, Qian LP, Chen ZQ. Expression of survivin in human gastric carcinoma and gastric carcinoma model of rats. World J Gastroenterol 2003; 9 (7): 1435-1438.

16. Fan L, Lin C, Zhuo $S$ et al. Transplantation with survivin-engineered mesenchymal stem cells results in beter prognosis in a rat model of myocardial infarction. Eur J Heart Failure 2009; 11: 1023-1030.

Received February 18, 2013. Accepted March 25, 2014. 